\title{
Effect of smoking on exhaled nitric oxide and flow-independent nitric oxide exchange parameters
}

\author{
A. Malinovschi*, C. Janson ${ }^{\#, \uparrow, ~ T . ~ H o l m k v i s t *, ~ D . ~ N o r b a ̈ c k ~}{ }^{\#,+}$, \\ P. Meriläinen ${ }^{f}$ and M. Högman*,\#,§
}

ABSTRACT: It is a well-known fact that smoking is associated with a reduction in exhaled nitric oxide (NO) levels. There is, however, limited knowledge relating to the smoking-induced changes in production or exchange of NO in different compartments of the airways.

This study comprised 221 adult subjects from the European Community Respiratory Health Survey II, who were investigated in terms of their exhaled NO, lung function, immunoglobulin E sensitisation and smoking habits. The following parameters were determined using extended NO analysis: airway tissue nitric oxide concentration (Caw,NO), airway transfer factor (or diffusing capacity) for nitric oxide (Daw,NO), alveolar nitric oxide concentration (CA,NO) and fractional exhaled nitric oxide concentration at a flow rate of $50 \mathrm{~mL} \cdot \mathrm{s}^{-1}(F \mathrm{eNO}, 0.05)$. Maximum total airway nitric oxide flux (J'aw,NO) was calculated from Daw,NO(Caw,NO-CA,NO).

Current smokers $(n=35)$ exhibited lower (geometric mean) FeNO,0.05 (14.0 versus $22.8 \mathrm{ppb}$ ), Caw,NO (79.0 versus $126 \mathrm{ppb}$ ) and J'aw,NO (688 versus 1,153 pL· $\left.\mathrm{s}^{-1}\right)$ than never-smokers $(\mathrm{n}=111)$. Ex-smokers $(n=75)$ were characterised by lower FeNO,0.05 (17.7 versus 22.8 ppb) and Jaw,NO (858 versus $1,153 \mathrm{pL} \cdot \mathrm{s}^{-1}$ ) than never-smokers. These relationships were maintained after adjusting for potential confounders (sex, age, height, immunoglobulin $E$ sensitisation and forced expiratory volume in one second), and, in this analysis, a negative association was found between current smoking and CA,NO. Snus (oral moist snuff) consumption $(n=21)$ in ex-smokers was associated with an increase in Daw,NO and a reduction in Caw,NO, after adjusting for potential confounders. Passive smoking was associated with a higher $\mathrm{CA}_{\mathrm{A}, \mathrm{NO}}$.

Using extended nitric oxide analysis, it was possible to attribute the reduction in exhaled nitric oxide levels seen in ex- and current smokers to a lower total airway nitric oxide flux in ex-smokers and reduced airway and alveolar nitric oxide concentrations in current smokers. The association between snus (oral tobacco) use and reduced nitric oxide concentrations in the airways and increased nitric oxide transfer from the airways warrants further studies.

KEYWORDS: Exhaled nitric oxide, extended nitric oxide analysis, oral tobacco, smoking

A reduction in exhaled nitric oxide (NO) levels was first observed in smokers in the early 1990s [1, 2], and this effect was found after both acute and chronic exposure to smoking [3]. Passive smoking has also been found to reduce levels of exhaled NO in healthy subjects [4] and asthmatic children [5]. Smoking cessation is accompanied by an increase in exhaled NO levels [6], and, in one report, NO levels normalised after smoking cessation [7].

The possible mechanisms by which exhaled NO levels are reduced in smoking subjects are a potential negative feedback mechanism of the NO from the cigarette smoke, which could lead to downregulation of NO synthase (NOS) in the lungs [8,9], an inadequate supply of cofactors necessary for NO production, such as tetrahydrobiopterin [10], and an increase in the breakdown of NO $[11,12]$.

By modelling NO exchange dynamics, it is possible to obtain greater insight into the two NO-producing compartments, the airways and alveoli, which are characterised by two or three flow-independent NO exchange parameters, depending on the model that is used. A review on this topic has been published recently [13]. The few studies investigating the effects of smoking on flow-independent $\mathrm{NO}$ exchange

\section{AFFILIATIONS}

Depts of *Medical Cell Biology, Integrative Physiology,

"Medical Sciences, Respiratory

Medicine and Allergology, and,

${ }^{+}$Medical Sciences, Occupational and

Environmental Medicine, and,

${ }^{\#}$ Asthma and Allergy Research

Centre, Uppsala University, Uppsala, and,

${ }^{\S}$ Dept of Caring Sciences and Sociology, Section of Medical

Science, University of Gävle, Gävle, Sweden, and

${ }^{f}$ Dept of Engineering Physics and Mathematics, Helsinki University of Technology, Helsinki, Finland.

CORRESPONDENCE

A. Malinovschi

Uppsala University

Dept of Medical Cell Biology

Integrative Physiology

Box 571

SE-751 23 Uppsala

Sweden

Fax: 46184714938

E-mail: Andrei.Malinovschi@

medcellbiol.uu.se

Received:

September 292005

Accepted after revision:

April 092006

\section{SUPPORT STATEMENT}

This study was supported by the Swedish Heart and Lung Foundation, the Varrdal Foundation for Health Care Science and Allergy Research, and the Swedish Association against Asthma and Allergy (all Stockholm, Sweden). The Agnes and Mac Rudberg Foundation and the Bror Hjerpstedt Foundation (both Uppsala, Sweden) also provided support for this study.

European Respiratory Journal Print ISSN 0903-1936 Online ISSN 1399-3003 
parameters indicate that smoking is related to a lower maximum total airway nitric oxide flux $\left(J^{\prime}\right.$ aw,NO) $[7,14]$ and to a lower mean airway tissue nitric oxide concentration $(\mathrm{Caw}, \mathrm{NO})$ [15]. There is, however, very limited information about the dose-response relationship and the effect of past and passive smoking on exhaled NO levels and flow-independent NO exchange parameters.

The aim of the present investigation was to study the effect of past, current and passive smoking on exhaled NO in a general population sample using flow-independent $\mathrm{NO}$ exchange parameters.

\section{MATERIAL AND METHODS}

\section{Population}

The subjects in the present study were participants in a followup of the European Community Respiratory Health Survey (ECRHS), which was performed in Uppsala during 1990-1991 [16]. Of the 622 subjects in the random sample of the ECRHS, 517 were reinvestigated 9 yrs later (1999-2000) in the ECRHS II [17]. The majority of the subjects who were reinvestigated $(n=368)$ were seen at the hospital for a clinical examination, whereas the remaining 149 subjects participated only in a telephone survey, usually because they had moved outside the study area between the two surveys.

Of the 368 subjects who attended for clinical examination, 225 $(61 \%)$ were also willing to perform exhaled NO measurements. In four of the subjects, information was lacking about their current smoking status; the present investigation, therefore, included 221 subjects.

\section{Questionnaires}

The ECHRS II main questionnaire [17] was used to obtain information about symptoms, diagnoses, smoking history and habits. Additionally, information about snus (oral moist snuff (tobacco)) consumption was obtained from the sleep questionnaire included in the Respiratory Health in Northern Europe study [18].

\section{Measurements of exhaled NO}

NO measurements were performed according to American Thoracic Society (ATS) recommendations, apart from the use of three additional flow rates $\left(5,100\right.$ and $\left.500 \mathrm{~mL} \cdot \mathrm{s}^{-1}\right)$ and no vital capacity manoeuvre, as a deep breath with slow inhalation was found to be sufficient [19].

The system used for NO measurements was a computer-based single-breath NO system from Nitrograf (Hässelby, Sweden), which used a chemiluminescence analyser (Sievers NOA 280; Sievers, Boulder, CO, USA). The system was calibrated using a mixture of $460 \mathrm{ppb} \mathrm{NO}$ in nitrogen (AGA, Lidingö, Sweden) and the zero was set by feeding synthetic air (AGA) into a 2-L canister filled with Purafil II chemisorbent with purakol (Lindair, Ljusne, Sweden). The flow sensor was calibrated in the range $0-0.6 \mathrm{~L} \cdot \mathrm{s}^{-1}$ (Dry Cal DC-2 flow calibrator; BIOS International, Pompton Plains, NJ, USA). Checks of the calibration and flow rate of the sampling system were made on a daily basis and the zero was controlled before each measurement. The expiratory pressure for all subjects ranged 5-20 $\mathrm{cm} \mathrm{H}_{2} \mathrm{O}$ in order to exclude a $\mathrm{NO}$ contribution from the nasal cavity. The mean value from three breaths (or two, if the
NO concentrations were identical from the two breaths) was used for statistical analysis.

\section{Application of the extended NO analysis}

The extended NO analysis has been previously described and validated [15]. Using the fractional exhaled NO concentration ( $F$ eNO) obtained at three different flow rates (5, 100 and $\left.500 \mathrm{~mL} \cdot \mathrm{s}^{-1}\right)$ and an iterative algorithm, it calculates the three flow-independent $\mathrm{NO}$ exchange parameters confined to the two compartments, the conducting airways, which are characterised by the Caw,NO and airway transfer factor (or diffusing capacity) for nitric oxide (Daw,NO), and the alveoli, characterised by the alveolar nitric oxide concentration $(\mathrm{CA}, \mathrm{NO})$. A fourth variable, J'aw,NO, was also used. J'aw,NO is calculated from $\mathrm{Daw}, \mathrm{NO}(\mathrm{Caw}, \mathrm{NO}-\mathrm{CA}, \mathrm{NO})$. The reason for including $J^{\prime}$ aw,NO in the present study was that it provides a global airway compartment description. The FeNO at a flow rate of $50 \mathrm{~mL} \mathrm{~s}^{-1}(\mathrm{FeNO}, 0.05)$ was used as a measure of overall exhaled NO concentration. It was decided to use the FeNO,0.05 in order to have a reference value for the other studies and to comply with ATS recommendations [20].

\section{Lung function}

Forced expiratory volume in one second (FEV1) was measured using a dry rolling-seal spirometer system (SensorMedics 2130; SensorMedics, Anaheim, CA, USA). Up to five technically acceptable blows were measured. ATS recommendations were followed [21]. The predicted values for FEV1 were calculated on the basis of European Coal and Steel Union reference values [22].

\section{Immunoglobulin E sensitisation}

Blood samples were collected for the measurement of total and specific serum immunoglobulin (Ig)E using the Pharmacia CAP System (Pharmacia Diagnostics, Uppsala, Sweden). Specific IgE directed against Dermatophagoides pteronyssinus, cat, timothy grass and Cladosporium herbarum were measured. The detection of a specific IgE concentration of $>0.35 \mathrm{kU} \cdot \mathrm{L}^{-1}$ was used as the definition of sensitisation to a specific allergen. $\operatorname{IgE}$ sensitisation was defined as sensitisation to at least one of the investigated allergens.

\section{Tobacco use}

Information on smoking history was collected by administering a questionnaire on each occasion. For those who answered "yes" to the lead question ("Have you ever smoked for as long as a year?"), additional questions were asked about age on starting, amount smoked currently, whether they had stopped or cut down, and the amount smoked previously. Based on this information, the subjects were classified as never-smokers, exsmokers and smokers. The mean number of cigarettes smoked per day was used to quantify exposure in current smokers. Lifetime exposure to smoking was calculated in pack-yrs. Latency was defined as being the period of time (in years) since ex-smokers had stopped smoking.

Never- and ex-smokers who answered in the affirmative to the question "Have you regularly (most days or nights) been exposed to tobacco smoke in the last 12 months?" were classified as passive smokers. 
Snus consumption was registered as a yes/no answer, without recording information about the amount consumed.

\section{Statistical methods}

NO values, mean daily cigarette consumption and pack-yrs of consumption were log-transformed before analysis. An unpaired t-test was used for comparisons between ex-smokers with and without snus consumption and in univariate analysis of the effects of sex and $\operatorname{IgE}$ sensitisation on exhaled $\mathrm{NO}$ and flow-independent NO exchange parameters. ANOVA was used when more than two groups were compared and Scheffé's test was used for multiple comparisons between the groups. Linear regression was used to test the correlation between exhaled $\mathrm{NO}$ and cigarette consumption, respectively, in the univariate analysis of the effect of height, age and FEV1 on exhaled $\mathrm{NO}$ and flow-independent NO exchange parameters. Multiple linear regression was used when analysing the effect of different explanatory variables on exhaled $\mathrm{NO}$ and the flow-independent NO exchange parameters. These models always included sex, age and FEV1 (variables shown to affect $\mathrm{CA}$,NO in the present study), height (which affected FeNO,0.05 and Daw,NO), and IgE sensitisation (which affected FeNO,0.05 and $\mathrm{Caw}, \mathrm{NO})$. A p-value of $<0.05$ was considered significant.

\section{Ethics}

All of the subjects gave their permission for the utilisation of their personal data for the purposes of the present study. The study was approved by the Ethics Committee of the Medical Faculty of Uppsala University (Uppsala, Sweden).

\section{RESULTS}

The study population comprised 115 males and 106 females. Their mean age was 43 yrs (range 29-54 yrs); 35 (15.8\%) were current smokers, 75 (33.9\%) ex-smokers and 15 (6.8\%) passive smokers. The subjects who underwent exhaled NO measurements did not differ from the other participants undergoing clinical examination in terms of sex, age, smoking history or passive smoking.

\section{Current smoking}

Current smokers exhibited significantly lower FeNO,0.05, Caw,NO and J'aw,NO than never-smokers (table 1). The current smokers differed from ex-smokers only in terms of Caw,NO $(p=0.02)$. No correlations could be found between daily cigarette consumption and FeNO,0.05 or the flow-independent NO exchange parameters.

The association between current smoking and FeNO,0.05, Caw,NO and J'aw,NO, respectively, remained significant when adjusting for sex, age, height, IgE sensitisation and FEV1 (table 2). In the multivariable analysis, a significant association was also found between $\mathrm{CA}, \mathrm{NO}$ and current smoking. In this analysis, height was associated with an increase in FeNO,0.05 $(\mathrm{p}=0.04)$, Daw,NO $(\mathrm{p}=0.03)$ and $J^{\prime} \mathrm{aw}, \mathrm{NO}(\mathrm{p}=0.03)$, whereas $\operatorname{IgE}$ sensitisation was associated with an increase in FeNO,0.05 $(p=0.003), C a w, N O(p=0.02)$ and $J^{\prime} a w, N O(p=0.004)$. Females exhibited higher $\mathrm{CA}, \mathrm{NO}$ than males $(\mathrm{p}<0.001)$. Age was positively associated with $\mathrm{CA}, \mathrm{NO}(\mathrm{p}=0.001)$. A significant negative association was found between FEV1 and $\mathrm{CA}_{\mathrm{N}} \mathrm{NO}$ $(\mathrm{p}<0.001)$.

\section{Past smoking}

Ex-smokers showed significantly lower FeNO,0.05 than neversmokers, whereas no significant differences were found for the

\section{TABLE 2} Association between exhaled nitric oxide (NO) variables and smoking history ${ }^{\#}$

Ex-smokers p-value Current smokers p-value

\begin{tabular}{lccccc}
\hline Subjects n & \multicolumn{2}{c}{72} & 35 & \\
FeNO,0.05 ppb & $-0.10(-0.18--0.02)$ & 0.01 & $-0.23(-0.32--0.13)$ & $<0.001$ \\
Caw,NO ppb & $-0.04(-0.12-0.03)$ & 0.29 & $-0.21(-0.30--0.11)$ & $<0.001$ \\
Daw,NO $\mathbf{~ L L} \cdot \mathbf{s}^{-1}$ & $-0.07(-0.14-0.005)$ & 0.07 & $-0.03(-0.12-0.07)$ & 0.56 \\
CA,NO ppb & $-0.01(-0.12-0.10)$ & 0.82 & $-0.20(-0.34--0.06)$ & 0.004 \\
J'aw,NO pL·s ${ }^{-1}$ & $-0.26(-0.46--0.05)$ & 0.01 & $-0.55(-0.80--0.29)$ & $<0.001$ \\
\hline
\end{tabular}

Data are presented as effect estimate (95\% confidence interval), unless otherwise stated. Nitric oxide variables are log-transformed. The effect estimate is the regression coefficient; however, it is difficult to transform this into a percentage increase/decrease since comparisons have been made between transformed and non-transformed data. FeNO,0.05: fractional exhaled nitric oxide concentration at a flow rate of $50 \mathrm{~mL} \cdot \mathrm{s}^{-1}$; Caw,NO: airway tissue nitric oxide concentration; Daw,NO: airway transfer factor (or diffusing capacity) for nitric oxide; CA,NO: alveolar nitric oxide concentration; J'aw,NO: maximum total airway nitric oxide flux. ${ }^{*}$ : after adjustment for age, sex, height, immunogloblulin $E$ sensitisation and forced expiratory volume in one second; $\uparrow$ : versus neversmokers $(n=103)$

\section{TABLE 1 Exhaled nitric oxide variables in never-, ex- and current smokers}

\begin{tabular}{|c|c|c|c|c|c|}
\hline & Never-smokers & Ex-smokers & p-value ${ }^{\#}$ & Current smokers & p-value ${ }^{\#}$ \\
\hline Subjects $\mathbf{n}$ & 111 & 75 & & 35 & \\
\hline$F \mathrm{eNO}, 0.05 \mathrm{ppb}$ & $22.8(20.3-25.7)$ & $17.7(15.7-20.1)$ & 0.02 & $14.0(11.2-17.6)$ & $<0.001$ \\
\hline Caw,NO ppb & $126(114-140)$ & $110(97-124)$ & 0.26 & 79.0 (63.0-99.0) & $<0.001$ \\
\hline Daw,NO $\mathrm{mL} \cdot \mathrm{s}^{-1}$ & $9.28(8.42-10.2)$ & 7.95 (6.99-9.05) & 0.18 & $8.87(7.05-11.2)$ & 0.92 \\
\hline CA,NO ppb & $1.32(1.13-1.54)$ & $1.41(1.14-1.73)$ & 0.88 & $0.93(0.67-1.28)$ & 0.12 \\
\hline$J ' a w, N O p L \cdot s^{-1}$ & $1153(1011-1315)$ & 858 (745-989) & 0.02 & $688(529-893)$ & 0.001 \\
\hline
\end{tabular}


other NO variables (table 1). The association between FeNO,0.05 and past smoking remained significant after excluding two exsmokers who had stopped smoking $<1$ yr previously $(p=0.03)$. The association also remained significant after adjusting for sex, age, height, IgE sensitisation and FEV1 (table 2).

In ex-smokers, the effects of smoking-related variables (amount previously smoked and latency respectively), snus consumption and lung function (assessed by FEV1) on exhaled $\mathrm{NO}$ levels were investigated. No associations were found between smoking-related variables and exhaled NO levels. Snus consumption in ex-smokers was associated with increased Daw,NO $(\mathrm{p}=0.04)$ on univariate analysis. The association between snus consumption and Caw,NO was just above the level of significance $(p=0.06$; fig. 1$)$. FEV1 was associated with a reduction in $\mathrm{CA}, \mathrm{NO}(\mathrm{p}=0.01)$. Multiple linear regression analysis was used to analyse and confirm these effects in ex-smokers after adjusting for confounding variables. The relationships were maintained and the association between snus consumption and $\mathrm{Caw}, \mathrm{NO}$ in ex-smokers became significant (table 3 ).
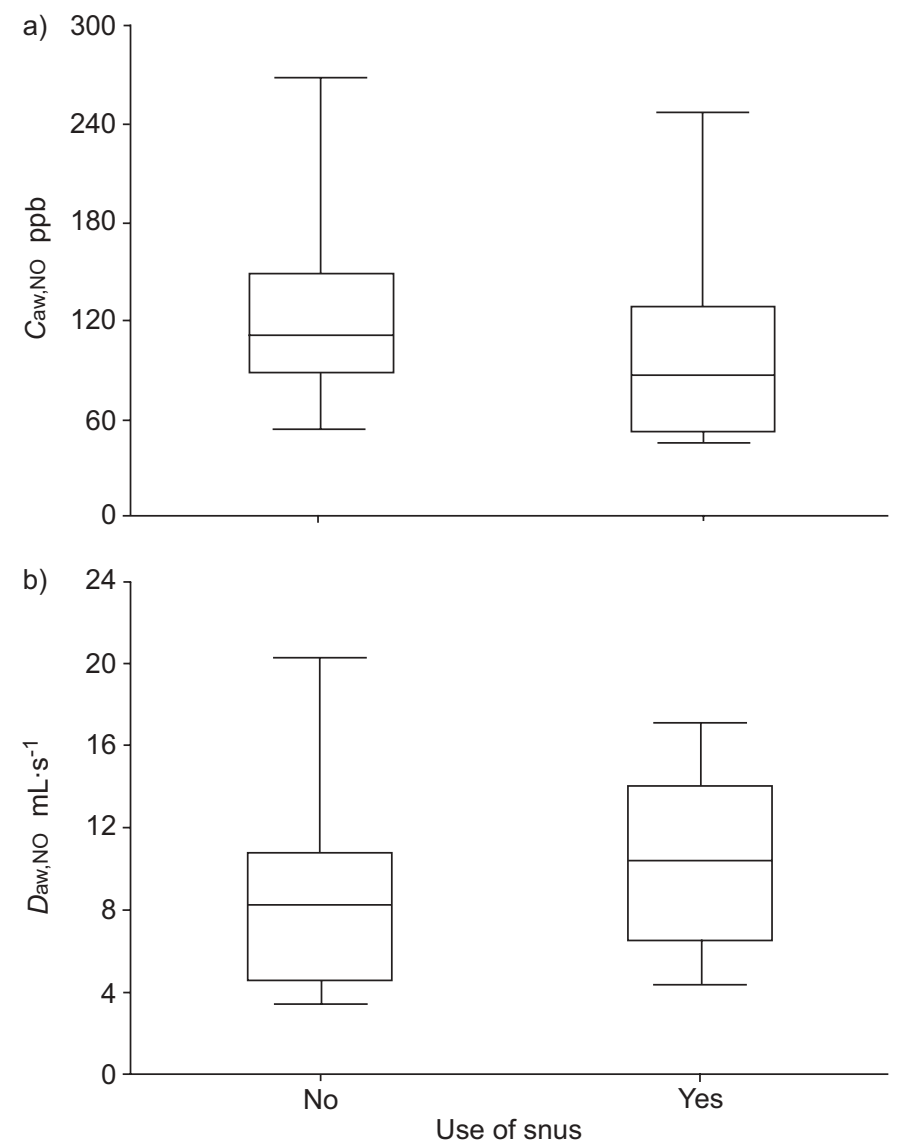

FIGURE 1. Boxplot showing association between use of snus (oral moist snuff; 21 users and 50 nonusers) in ex-smokers and: a) airway tissue nitric oxide concentration (Caw,NO; $\mathrm{p}=0.06$ ); and $\mathrm{b}$ ) airway transfer factor (or diffusing capacity) for nitric oxide ( $\mathrm{Daw}, \mathrm{NO} ; \mathrm{p}=0.04)$. Boxes represent median and interquartile range; horizontal bars represent 5 th-95th percentile range.

\section{Passive smoking}

Nonsmokers who were passive smokers exhibited significantly higher $\mathrm{CA}, \mathrm{NO}$ than subjects who were not exposed, whereas there were no significant differences in terms of the other exhaled NO variables (table 4). The association between passive smoking and increased $\mathrm{CA}, \mathrm{NO}$ remained significant after adjustment for age, sex, height, IgE sensitisation and FEV1 $(p=0.008)$.

\section{DISCUSSION}

The main finding of the present study is that current smoking is associated with a reduction in $\mathrm{Caw}, \mathrm{NO}$ and $\mathrm{CA}, \mathrm{NO}$. It was also found that ex-smokers exhibited lower levels of exhaled NO than never-smokers, which was reflected in a lower $J^{\prime}$ aw,NO, and that passive smoking was associated with increased CA,NO. A surprising and novel finding was that, in ex-smokers, snus consumption was associated with a reduction in Caw,NO and an increase in Daw,NO.

The model used in the present article to determine the NO flow-independent parameters has been validated [19] against the classical slope-intercept model [23]. The choice of flow rates and method used to analyse the data affects the estimation of NO flow-independent parameters [13]. Decreasing the highest flow rate increased the estimated $\mathrm{CA}, \mathrm{NO}$ in a recent article that used a linear regression method and FeNO measurements at three flow rates ranging 100$200 \mathrm{~mL} \cdot \mathrm{s}^{-1}$ [24]. The choice of lowest flow rate affects the estimation of Caw,NO and Daw,NO, and, theoretically, Caw,NO would be estimated more accurately by using as low as possible a flow rate, since the measured exhaled NO would be Caw,NO at a flow rate that tends towards $0 \mathrm{~mL} \cdot \mathrm{s}^{-1}$.

The reduction in Caw,NO in current smokers is in accordance with a previous study [15]. A recent study [25] was not able to demonstrate differences between smokers and nonsmokers in terms of the nonenzymatic production of NO and suggested that the lower levels of exhaled NO in smokers might be due to the downregulation of enzymatic NO production in the oropharyngeal and bronchial compartment. A negative feedback mechanism caused by the high levels of NO in cigarette smoke was postulated, in the early 1990s, as a possible mechanism [8], but this was only confirmed in 2003, in the case of inducible NOS in lung epithelial cells [9]. Smoking is associated with reduced levels of tetrahydrobiopterin [10], which might reduce enzymatic NO production by uncoupling NOS, with resultant production of superoxide instead of NO [26]. Superoxide can, in turn, react with NO to form peroxynitrite. The fact that $\mathrm{NO}$ consumption might be increased in smokers' airways is also suggested by the increase in NO metabolites in exhaled breath condensate [12, 27].

In the present study, current smoking was also associated with reduced $C A, N O$. This result is in accordance with a study of DelClaux et al. [14], who measured FeNO at six different flow rates, ranging $50-300 \mathrm{~mL} \cdot \mathrm{s}^{-1}$, and used least-squares linear regression in order to obtain CA,NO and J'aw,NO. DELClAuX et al. [14] found a trend towards higher values in healthy nonsmokers versus healthy smokers, but contradicted the results of two previous studies demonstrating either higher $\mathrm{CA}, \mathrm{NO}$ in smokers [7], when linear regression was used on FeNO measurements performed at five flow rates, ranging $50-320 \mathrm{~mL} \cdot \mathrm{s}^{-1}$, or no 
TABLE 3 Association between exhaled nitric oxide variables and smoking-related variables in ex-smokers ${ }^{\#}$

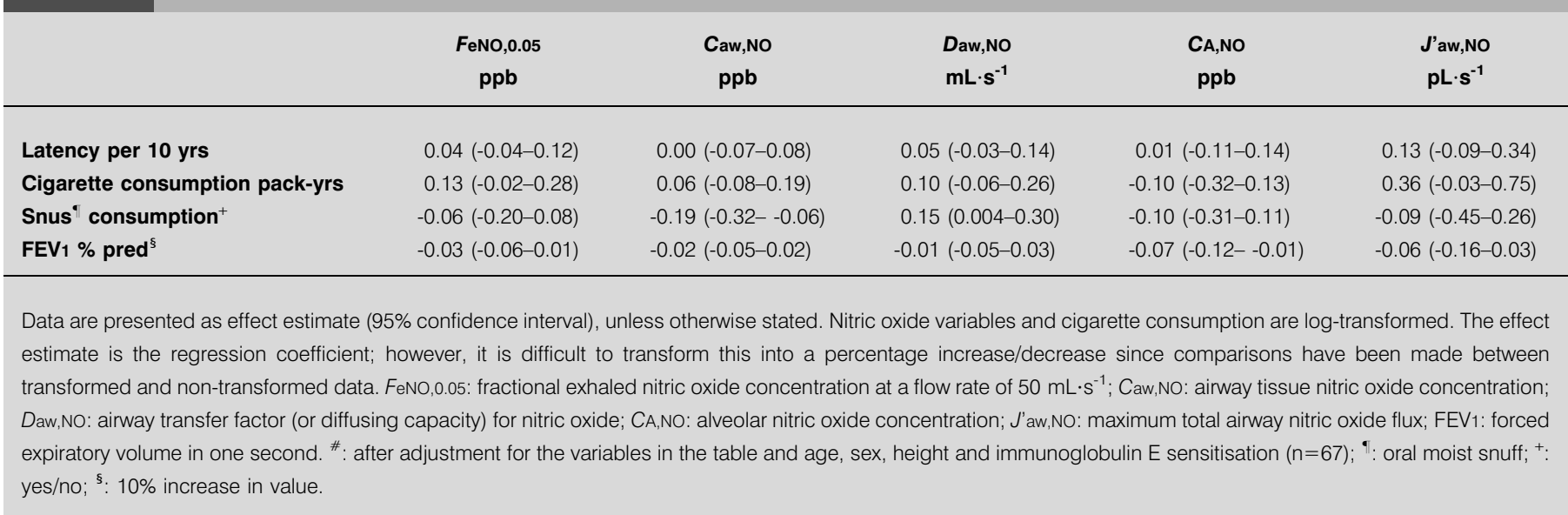

difference in $\mathrm{CA}, \mathrm{NO}$, in a study that used the same flow rates and model as the present study [15]. One explanation for this apparent discrepancy might be that the results were adjusted for possible confounders, something that was not undertaken in the previous studies. Another possible methodological explanation for this difference might be the fact that the present study is based on a general population sample, whereas the previous investigations comprised healthy nonsmokers versus healthy smokers. THERRIAULT et al. [28] reported that the $N$-nitrosamine 4(N-methylnitrosamino)-1-(3-pyridyl)-1-butanone, a component of cigarette smoke, inhibited alveolar macrophages from producing NO, a finding that might explain the lower $\mathrm{CA}_{\mathrm{A}} \mathrm{NO}$ in smokers. Another possible mechanism could be an increase in the permeability of the respiratory membrane for $\mathrm{NO}$ in chronic smokers [29].

It was not possible to find a dose-response relationship when studying the number of cigarettes smoked and levels of exhaled NO. This observation apparently contradicts a previous study of KHARITONOV et al. [3], in which a strong correlation between the number of cigarettes smoked and FeNO was found, but this study was conducted in 1995 and used peak and not plateau exhaled NO concentrations, as in the current recommendations, which were followed in the present

\begin{tabular}{|c|c|c|c|}
\hline LEE 4 & $\begin{array}{l}\text { Exhaled nitric oxide in } \\
\text { exposed and exposed }\end{array}$ & $\begin{array}{l}\text { onsmoking suk } \\
\text { tobacco smc }\end{array}$ & cts not \\
\hline & Not exposed & Exposed & p-value \\
\hline Subjects $n$ & 167 & 15 & \\
\hline$F_{\mathrm{eNO}, 0.05 \mathrm{ppb}}$ & 20.7 (18.9-22.7) & $20.3(14.2-29.1)$ & 0.92 \\
\hline Caw,NO ppb & $119(110-129)$ & $126(94.2-168)$ & 0.70 \\
\hline Daw,NO $\mathrm{mL} \cdot \mathrm{s}^{-1}$ & $8.79(8.10-9.54)$ & $7.78(5.63-10.7)$ & 0.40 \\
\hline$C_{A, N O}$ ppb & $1.29(1.13-1.48)$ & $2.31(1.82-2.93)$ & 0.01 \\
\hline J'aw,NO pL·s ${ }^{-1}$ & $1030(929-1142)$ & $959(632-1454)$ & 0.70 \\
\hline
\end{tabular}

Data are presented as geometric mean (95\% confidence interval), unless otherwise stated. FeNO,0.05: fractional exhaled nitric oxide concentration at a flow rate of $50 \mathrm{~mL} \cdot \mathrm{s}^{-1}$; Caw,NO: airway tissue nitric oxide concentration; Daw,NO: airway transfer factor (or diffusing capacity) for nitric oxide; $\mathrm{CA}, \mathrm{NO}$ : alveolar nitric oxide concentration; J'aw,NO: maximum total airway nitric oxide flux. study. TAKAHASHI et al. [30] looked at end-expiratory levels of $\mathrm{NO}$ and reported that levels of exhaled NO were not related to the number of cigarettes smoked.

In the present study, ex-smokers exhibited lower FeNO,0.05 and $J$ 'aw,NO than never-smokers, and this difference remained after adjusting for sex, age, height, IgE sensitisation and FEV1. These results are in accordance with those of RoBBins et al. [6], who reported an increase in FeNO but even lower levels of mean oral NO than in controls after 8 weeks of smoking cessation. The results are not in accordance with a previous study in which it was found that 4 weeks of smoking cessation resulted in an increase in FeNO in the ex-smoker group up to the same level as the healthy nonsmoking controls [7]. This apparent discrepancy may be due to the fact that some of the subjects in the smoking cessation group in the previous study showed allergic symptoms and therefore higher baseline FeNO than the healthy controls, who were all nonallergic. The present results point towards a reduction in NO transfer through the apical membrane of the airway epithelial cells, which could be explained by the fact that smoking has been associated with the keratinisation of epithelial cells, as seen for oral mucosa [31] and tracheal epithelium [32], impeding NO diffusion.

In the present study, no association was found between FeNO,0.05 and latency or amount of previous smoking in exsmokers. However, somewhat surprisingly, it was found that snus consumption was associated with a reduction in $\mathrm{Caw}, \mathrm{NO}$ and an increase in Daw,NO in ex-smokers. One possible reason for the reduction in $\mathrm{Caw}, \mathrm{NO}$ in snus users may be an increase in the consumption of $\mathrm{NO}$ in the airways, possibly due to the transformation of $\mathrm{NO}$ to peroxynitrite. This suggestion is supported by the observations of HELEN et al. [33], who found nicotine-induced peroxidative damage in the lungs, heart and liver of rats. A similar observation was made by IHO et al. [34], who looked at nicotine-stimulated neutrophils and noted that neutrophilic production of NO was reduced, suggesting that superoxide, produced by nicotine, generates peroxynitrite by reacting with preformed NO.

The other observation, which was that Daw,NO was increased in snus consumers, might be explained by the higher oral production seen in snus users due to bacterial colonisation. The bacterial colonisation might be explained by the poorer 
oral hygiene reported in snus consumers, which would create a local environment in the oral mucosa conducive to bacterial growth and colonisation [35]. There is evidence that the nicotine concentrations reported in the saliva of snus consumers might have a stimulatory effect on bacterial growth [36]. An alternative or complementary explanation could be the high nitrate content of snus [37], which can be transformed in the oral cavity to nitrite by bacterial activity. Nitrite could subsequently be used as substrate to produce NO. The hypothesis that increased NO production in the oral cavity is reflected in the Daw,NO was indirectly supported by TöRNBERG et al. [38], who observed that, in tracheotomised subjects, the removal of the oropharyngeal compartment led to a significant reduction in Daw,NO, without affecting the other flowindependent NO exchange parameters. TöRNBERG et al. [38] measured exhaled $\mathrm{NO}$ at six different flow rates ranging 6$300 \mathrm{~mL} \cdot \mathrm{s}^{-1}$ and used a nonlinear regression method to obtain Caw,NO, Daw,NO and CA,NO.

It was not possible to demonstrate that reported passive smoking in nonsmokers was associated with reduced levels of exhaled NO. This finding is in agreement with some previous studies [39-41] and also in partial agreement with the study of WARKE et al. [5], which used questionnaire assessment of smoke exposure and was unable to show any effect of smoke exposure on FeNO in nonasthmatic children, although it was found in asthmatic children. It should be noted that the previous studies were conducted in a population of children and that the only available studies in adults have focused exclusively on the immediate effects of smoking [4, 42]. It was found that passive smoking was associated with increased $\mathrm{CA}, \mathrm{NO}$, but, at the present time, the current authors have no clear idea as to the mechanism behind this observation. One possible explanation might be offered by the reduced permeability of the respiratory membrane seen in subjects exposed to sidestream smoke [43].

The present investigation is one of the first studies to investigate flow-independent $\mathrm{NO}$ exchange parameters in a general population sample. The utilisation of objective markers of tobacco consumption and exposure would have been better, even though there are studies showing a reasonable association between self-reported and objectively measured tobacco use and exposure [44-46].

The use of flow-independent nitric oxide exchange parameters may aid understanding of the location of tobacco-induced changes in airway nitric oxide metabolism and exchange. In the present study, both current and past smoking were associated with reduced levels of exhaled nitric oxide. In current smokers, reduced nitric oxide levels were found in both the airways and alveoli, whereas, in ex-smokers, the maximum total airway nitric oxide flux was reduced. The association between snus (oral moist snuff) and reduced nitric oxide concentrations in the airways and increased nitric oxide transfer from the airways warrants further studies.

\section{REFERENCES}

1 Persson MG, Zetterstrom O, Agrenius V, Ihre E, Gustafsson LE. Single-breath nitric oxide measurements in asthmatic patients and smokers. Lancet 1994; 343: 146-147.

2 Schilling J, Holzer P, Guggenbach M, Gyurech D, Marathia K, Geroulanos S. Reduced endogenous nitric oxide in the exhaled air of smokers and hypertensives. Eur Respir J 1994; 7: 467-471.

3 Kharitonov SA, Robbins RA, Yates D, Keatings V, Barnes PJ. Acute and chronic effects of cigarette smoking on exhaled nitric oxide. Am J Respir Crit Care Med 1995; 152: 609-612.

4 Yates DH, Breen H, Thomas PS. Passive smoke inhalation decreases exhaled nitric oxide in normal subjects. Am J Respir Crit Care Med 2001; 164: 1043-1046.

5 Warke TJ, Mairs V, Fitch PS, Ennis M, Shields MD. Possible association between passive smoking and lower exhaled nitric oxide in asthmatic children. Arch Environ Health 2003; 58: 613-616.

6 Robbins RA, Millatmal T, Lassi K, Rennard S, Daughton D. Smoking cessation is associated with an increase in exhaled nitric oxide. Chest 1997; 112: 313-318.

7 Hogman M, Holmkvist T, Walinder R, et al. Increased nitric oxide elimination from the airways after smoking cessation. Clin Sci (Lond) 2002; 103: 15-19.

8 Assreuy J, Cunha FQ, Liew FY, Moncada S. Feedback inhibition of nitric oxide synthase activity by nitric oxide. Br J Pharmacol 1993; 108: 833-837.

9 Hoyt JC, Robbins RA, Habib M, et al. Cigarette smoke decreases inducible nitric oxide synthase in lung epithelial cells. Exp Lung Res 2003; 29: 17-28.

10 Higman DJ, Strachan AM, Buttery L, et al. Smoking impairs the activity of endothelial nitric oxide synthase in saphenous vein. Arterioscler Thromb Vasc Biol 1996; 16: 546-552.

11 Balint B, Donnelly LE, Hanazawa T, Kharitonov SA, Barnes PJ. Increased nitric oxide metabolites in exhaled breath condensate after exposure to tobacco smoke. Thorax 2001; 56: 456-461.

12 Corradi M, Pesci A, Casana R, et al. Nitrate in exhaled breath condensate of patients with different airway diseases. Nitric Oxide 2003; 8: 26-30.

13 George SC, Hogman M, Permutt S, Silkoff PE. Modeling pulmonary nitric oxide exchange. J Appl Physiol 2004; 96: 831-839.

14 Delclaux C, Mahut B, Zerah-Lancner F, et al. Increased nitric oxide output from alveolar origin during liver cirrhosis versus bronchial source during asthma. Am J Respir Crit Care Med 2002; 165: 332-337.

15 Hogman M, Holmkvist T, Wegener T, et al. Extended NO analysis applied to patients with COPD, allergic asthma and allergic rhinitis. Respir Med 2002; 96: 24-30.

16 Janson C, Anto J, Burney $\mathrm{P}$, et al. The European Community Respiratory Health Survey: what are the main results so far? Eur Respir J 2001; 18: 598-611.

17 European Community Respiratory Health Survey Steering Committee. The European Community Respiratory Health Survey II. Eur Respir J 2002; 20: 1071-1079.

18 Franklin KA, Gislason T, Omenaas E, et al. The influence of active and passive smoking on habitual snoring. Am J Respir Crit Care Med 2004; 170: 799-803.

19 Hogman M, Drca N, Ehrstedt C, Merilainen P. Exhaled nitric oxide partitioned into alveolar, lower airways and nasal contributions. Respir Med 2000; 94: 985-991. 
20 American Thoracic Society. Recommendations for standardized procedures for the online and offline measurement of exhaled lower respiratory nitric oxide and nasal nitric oxide in adults and children - 1999. Am J Respir Crit Care Med 1999; 160: 2104-2117.

21 American Thoracic Society. Standardization of spirometry, 1994 update. Am J Respir Crit Care Med 1995; 152: 1107-1136.

22 Quanjer PH. Standardized lung function testing. Report Working Party Standardization of Lung Function Tests, European Community for Coal and Steel. Bull Eur Physiopathol Respir 1983; 19: Suppl. 5, 1-95.

23 Tsoukias NM, George SC. A two-compartment model of pulmonary nitric oxide exchange dynamics. J Appl Physiol 1998; 85: 653-666.

24 Gelb AF, Taylor CF, Nussbaum E, et al. Alveolar and airway sites of nitric oxide inflammation in treated asthma. Am J Respir Crit Care Med 2004; 170: 737-741.

25 Marteus H, Mavropoulos A, Palm JP, Ulfgren AK, Bergstrom J, Alving K. Nitric oxide formation in the oropharyngeal tract: possible influence of cigarette smoking. Nitric Oxide 2004; 11: 247-255.

26 Wever RM, van Dam T, van Rijn HJ, de Groot F, Rabelink TJ. Tetrahydrobiopterin regulates superoxide and nitric oxide generation by recombinant endothelial nitric oxide synthase. Biochem Biophys Res Commun 1997; 237: 340-344.

27 Garey KW, Neuhauser MM, Robbins RA, Danziger LH, Rubinstein I. Markers of inflammation in exhaled breath condensate of young healthy smokers. Chest 2004; 125: 22-26.

28 Therriault MJ, Proulx LI, Castonguay A, Bissonnette EY. Immunomodulatory effects of the tobacco-specific carcinogen, NNK, on alveolar macrophages. Clin Exp Immunol 2003; 132: 232-238.

29 Jones JG, Minty BD, Lawler P, Hulands G, Crawley JC, Veall N. Increased alveolar epithelial permeability in cigarette smokers. Lancet 1980; 1: 66-68.

30 Takahashi Y, Kobayashi H, Takahashi Y, Mitsufuji H, Tomita T. [A standard manoeuvre to measure the concentration of exhaled nitric oxide.]. Nihon Kyobu Shikkan Gakkai Zasshi 1997; 35: 596-601.

31 Mosadomi A, Shklar G, Loftus ER, Chauncey HH. Effects of tobacco smoking and age on the keratinization of palatal mucosa: a cytologic study. Oral Surg Oral Med Oral Pathol 1978; 46: 413-417.

32 Rutten AA, Bruyntjes JP, Ramaekers FC. Effect of cigarette smoke condensate and vitamin A depletion on keratin expression patterns in cultured hamster tracheal epithelium. An immunohistomorphological study using monoclonal antibodies to keratins. Virchows Arch B Cell Pathol Incl Mol Pathol 1988; 56: 111-117.
33 Helen A, Krishnakumar K, Vijayammal PL, Augusti KT. Antioxidant effect of onion oil (Allium cepa. Linn) on the damages induced by nicotine in rats as compared to alphatocopherol. Toxicol Lett 2000; 116: 61-68.

34 Iho S, Tanaka $Y$, Takauji R, et al. Nicotine induces human neutrophils to produce IL-8 through the generation of peroxynitrite and subsequent activation of NF-кB. J Leukoc Biol 2003; 74: 942-951.

35 Rubinstein I, Pedersen GW. Bacillus species are present in chewing tobacco sold in the United States and evoke plasma exudation from the oral mucosa. Clin Diagn Lab Immunol 2002; 9: 1057-1060.

36 Keene K, Johnson RB. The effect of nicotine on growth of Streptococcus mutans. Miss Dent Assoc J 1999; 55: 38-39.

37 Brunnemann KD, Qi J, Hoffmann D. Chemical profile of two types of oral snuff tobacco. Food Chem Toxicol 2002; 40: 1699-1703.

38 Törnberg DC, Bjorne H, Lundberg JO, Weitzberg E. Multiple single-breath measurements of nitric oxide in the intubated patient. Am J Respir Crit Care Med 2003; 168: 1210-1215.

39 Franklin PJ, Taplin R, Stick SM. A community study of exhaled nitric oxide in healthy children. Am J Respir Crit Care Med 1999; 159: 69-73.

40 Barreto M, Villa MP, Martella S, et al. Exhaled nitric oxide in asthmatic and non-asthmatic children: influence of type of allergen sensitization and exposure to tobacco smoke. Pediatr Allergy Immunol 2001; 12: 247-256.

41 Janson C, Kalm-Stephens P, Foucard T, Norback D, Alving K, Nordvall SL. Exhaled nitric oxide levels in school children in relation to IgE sensitisation and window pane condensation. Respir Med 2005; 99: 1015-1021.

42 Maniscalco M, Di Mauro V, Farinaro E, Carratu L, Sofia M. Transient decrease of exhaled nitric oxide after acute exposure to passive smoke in healthy subjects. Arch Environ Health 2002; 57: 437-440.

43 Yates DH, Havill K, Thompson MM, Rittano AB, Chu J, Glanville AR. Sidestream smoke inhalation decreases respiratory clearance of ${ }^{99 \mathrm{~m}} \mathrm{Tc}$-DTPA acutely. Aust $\mathrm{N} \mathrm{Z} \mathrm{J}$ Med 1996; 26: 513-518.

44 Cabrera de Leon A, Almeida GD, Perez ML, et al. Tabaquismo en adolescentes. Prevalencia estimada mediante declaración y cotinina sérica. [Cigarette smoking among adolescents. Estimated prevalence by a questionnaire and serum cotinine]. Gac Sanit 1999; 13: 270-274.

45 McDonald SP, Maguire GP, Hoy WE. Validation of selfreported cigarette smoking in a remote Australian Aboriginal community. Aust N Z J Public Health 2003; 27: 57-60.

46 Riboli E, Preston-Martin S, Saracci R, et al. Exposure of nonsmoking women to environmental tobacco smoke: a 10-country collaborative study. Cancer Causes Control 1990; 1: 243-252. 